УДК 336.76

Ніколаєва А.М., к.е.н., доцент

Nikolaieva A. Candidate of Economic Sciences, Associate Professor https://orcid.org/0000-0003-3531-2023

\title{
ТЕОРЕТИКО-МЕТОДОЛОГІЧНІ АСПЕКТИ ОЦНКИ ЕФЕКТИВНОСТІ ФІНАНСОВОГО РИНКУ
}

\author{
Луцький національний технічний університет
}

У статті досліджено теоретичні підходи до дефініції «ефективність фінансового ринку» та визначено методологію ії̈ оцінки з позиції виконання фінансовим ринком його макроекономічної функції. Проаналізовано та узагальнено основоположні концепції ефективності фінансового ринку, розроблені американськими вченими. Визначено сутність ефективного ринку та виділено форми його ефективності за гіпотезою ефективного ринку Ю. Фами, теорії інвестиційного цінного паперу В. Шарпа, альтернативної гіпотези ефективного ринку Т. Коупленда і Дж. Вестона, концепції витрат фінансового посередництва К. Ерроу, Р. Лукаса та П. Ромера. Обгрунтовано, що не всі висунуті науковцями умови ефективності фінансового ринку дотримуються на реальному ринку. Вказано на суперечність рівняння ефективності фінансового ринку, що визначається як величина, обернена різниці відсоткових ставок по кредитах i депозитах в банківській системі.

Автором обгрунтовано, що макроекономічну ефективність фінансового ринку та іiі роль у забезпеченні стабільного розвитку соціально-економічних систем, в першу чергу, визначає розподільна (перерозподільна) функція фінансового ринку. Зазначено, що ефективний фінансовий ринок має бути рушійною силою, що стимулює стабільний розвиток і позитивні зрушення в економіці, забезпечуючи підприємства інвестиційно-кредитними ресурсами.

За макроекономічною роллю в ринковій економіці, ефективність фінансового ринку автором визначається як його здатність забезпечувати ефективний перерозподіл ресурсів, спрямовуючи їх в реальний сектор економіки, що призводить до стабільного розвитку соціально-економічних систем. При цьому ефективність фінансового ринку за його розподільною функцією пропонується оцінювати за показником співвідношення суми реально залученого капіталу нефінансовими корпораціями та сукупної ресурсної бази фінансового ринку.

Здійснено порівняльний аналіз впливу стану розвитку основних сегментів фінансового ринку (фондового та кредитного ринків) на економічний розвиток різних країн за ключовими показниками, що надаються Всесвітньою федерацією бірж та Міжнародним Валютним Фондом.

Ключові слова: інформаційна, иінова, операційна ефективність фінансового ринку, ефективність розподілу, масштаб фінансового ринку.

\section{THEORETICAL AND METHODOLOGICAL ASPECTS OF EVALUATION OF FINANCIAL MARKET EFFICIENCY}

\section{Lutsk National Technical University}

The article examines the theoretical approaches to the definition of "financial market efficiency" and defines the methodology for its evaluation from the standpoint of financial market performance of its macroeconomic function. The basic concepts of financial market efficiency developed by American scientists are analyzed and generalized. The essence of an efficient market is determined and the forms of its efficiency are determined according to the hypothesis of an efficient market by E. Fama, the theory of investment security by W. Sharpe, the alternative hypothesis of an efficient market by T. Copeland and J. Weston, the concept of financial intermediation costs K. Arrow, R. Lucas and P. Romer. It is substantiated that not all conditions of efficiency of the financial market put forward by scientists are observed in the real market. The contradiction of the equation of efficiency of the financial market, which is defined as the value inverse of the difference in interest rates on loans and deposits in the banking system, is pointed out.

The author substantiates that the macroeconomic efficiency of the financial market and its role in ensuring the stable development of socio-economic systems is primarily determined by the distributive (redistributive) function of the financial market. It is noted that an effective financial market should be the driving force that stimulates stable development and positive changes in the economy, providing enterprises with investment and credit resources. 
According to the macroeconomic role in a market economy, the efficiency of the financial market is defined by the author as its ability to ensure effective redistribution of resources, directing them to the real sector of the economy, which leads to stable development of socio-economic systems. At the same time, the efficiency of the financial market by its distribution function is proposed to be assessed by the ratio of the amount of actually attracted capital by non-financial corporations and the total resource base of the financial market.

A comparative analysis of the impact of the state of development of the main segments of the financial market (stock and credit markets) on the economic development of different countries on key indicators provided by the World Federation of Exchanges and the International Monetary Fund.

Key words: information, price, operational efficiency of the financial market, efficiency of distribution, scale of the financial market.

Постановка проблеми у загальному вигляді i її зв'язок з важливими науковими та практичними завданнями. Економічне зростання будь-якої країни, що функціонує на ринкових засадах, неможливе без дієвого, ефективного фінансового ринку, головне завдання якого полягає у перерозподілі капіталу між сферами економіки та забезпеченні суб'єктів господарювання інвестиційно-кредитними ресурсами. В сучасних умовах глобальних викликів, що супроводжуються періодичними фінансовоекономічними кризами, вплив фінансового ринку на реальний сектор економіки лише зростатиме. Тому, добре функціонуючий або ефективний фінансовий ринок - це запорука розвитку національної та регіональних соціально-економічних систем. При цьому, в процесі дослідження впливу фінансового ринку на економічне зростання країни постає необхідність у чіткій ідентифікації самого поняття «ефективності фінансового ринку» та методів іiї оцінювання, зважаючи на існуючу різноманітність та абсолютно різні теоретико-методологічні підходи в теорії фінансового ринку.

Аналіз останніх досліджень, у яких започатковано вирішення проблеми. В наукових колах вже тривалий час розглядається спірне питання, який же фінансовий ринок слід вважати ефективним, а також, яка роль концепції ефективності ринку в сучасних умовах. Як відомо, основні концепції сучасного фінансового ринку розроблені в США американськими вченими-економістами (Джеймсом Тобіном, Гаррі Марковіцем, Вільямом Шарпом, Мертоном Міллером, Юджином Фамою, Робертом Джеймсом Шиллером, Джорджем Акерлофом, Майклом Спенсом, Джозефом Стігліцем та їхніми послідовниками). На важливість та прагматизм цих теорій, а також їх значимість для суб'єктів сучасного фінансового ринку та економіки країн в цілому вказує те, що їх автори стали лауреатами Нобелівських премій 3 економіки в різні роки. Серед вітчизняних науковців, що досліджували окремі аспекти функціонування ефективного фінансового ринку та його макроекономічної ролі, слід відзначити праці Ж.В. Гарбар, С.М. Еш, В.В. Корнєєва, О.М. Мозгового, Н.С. Рязанової, В.Л. Смагіна, В.М. Шелудько, I.O. Школьник та багатьох інших. При цьому, зважаючи на існуючу критику сучасних теорій фінансового ринку, що час від часу з'являється з боку теоретиків і практиків, особливо після фінансових криз в економіці, слід відзначити відсутність на теперішній час в наукових джерелах єдиного підходу до трактування поняття «ефективність фінансового ринку».

Цілі статті. Метою статті є дослідження теоретико-методологічних підходів до дефініції «ефективність фінансового ринку» та її оцінки з позиції виконання фінансовим ринком його макроекономічної функції.

Виклад основного матеріалу дослідження 3 повним обгрунтуванням отриманих наукових результатів. У фінансовій науково-практичній літературі зустрічаються різні концепції ефективності фінансового ринку. Результати дослідження основних 3 них наведено автором у [1] та узагальнено й систематизовано в таблиці 1.

Найчастіше в наукових джерелах ефективність фінансового ринку пов'язують 3 його інформаційною функцією. Цей підхід базується на гіпотезі ефективного ринку американського економіста, Нобелівського лауреата з економіки 2013 року Юджина 
Фами (англ. Eugene F. Fama), яка свідчить, що «вся суттєва інформація негайно і повною мірою відбивається на ринковій курсовій вартості цінних паперів» [2].

Таблиця 1

Основоположні концепції ефективності фінансового ринку

\begin{tabular}{|c|c|c|}
\hline $\begin{array}{c}\text { Концепції ефективності } \\
\text { фінансового ринку, } \\
\text { представники }\end{array}$ & Сутність ефективного ринку & $\begin{array}{c}\text { Форми ефективності фінансового } \\
\text { ринку }\end{array}$ \\
\hline $\begin{array}{l}\text { Гіпотеза ефективного } \\
\text { ринку (Ю. Фама) }\end{array}$ & $\begin{array}{l}\text { «... ринок є ефективним щодо } \\
\text { деякої інформації, якщо вона } \\
\text { відразу і повністю відбивається в } \\
\text { ціні активу, що робить цю } \\
\text { iнформацію непотрібною для } \\
\text { отримання надприбутків» [2]. }\end{array}$ & $\begin{array}{l}\text { Слабка форма ефективності-ціни } \\
\text { акцій відбивають усю інформацію } \\
\text { щодо торгівлі ними у минулому. } \\
\text { Середня форма (напівсильна) - ціни } \\
\text { акцій відображають усю } \\
\text { загальнодоступну індемацію } \\
\text { (минулу і поточну публічну } \\
\text { інформацію). } \\
\text { Сильна форма ефективності-ціни } \\
\text { акцій відбивають усю інформацію, } \\
\text { що відноситься до фірми-емітента, у } \\
\text { т. ч. і внутрішню (інсайдерську). }\end{array}$ \\
\hline $\begin{array}{lr}\text { Tеорія } & \text { інвестиційної } \\
\text { вартості цінного п паперу } \\
\text { (В. Шарп) }\end{array}$ & $\begin{array}{l}\text { «... ринок } є \text { ефективним, якщо, } \\
\text { використовуючи } \\
\text { iнформацію, не можна отримати } \\
\text { відмінний від } \text { нормального } \\
\text { прибуток або } \text { надприбуток } \\
\text { (abnormal profit). Отже, на } \\
\text { ефективному ринку інвестори } \\
\text { повинні одержувати тільки } \\
\text { нормальний прибуток і нормальну } \\
\text { ставку дохідності за своїми } \\
\text { iнвестиціями» }[4, \text { с. } 109] .\end{array}$ & $\begin{array}{l}\text { «Абсолютно ефективний ринок } \\
\text { являє собою такий ринок, на якому } \\
\text { ціна на кожний цінний папір завжди } \\
\text { дорівнює їі інвестиційній вартості» } \\
{[4, \text { с. } 108] \text {. }}\end{array}$ \\
\hline $\begin{array}{l}\text { Альтернативна концепція } \\
\text { гіпотези ефективного } \\
\text { ринку т. Коупленда і } \\
\text { Дж. Вестона }\end{array}$ & 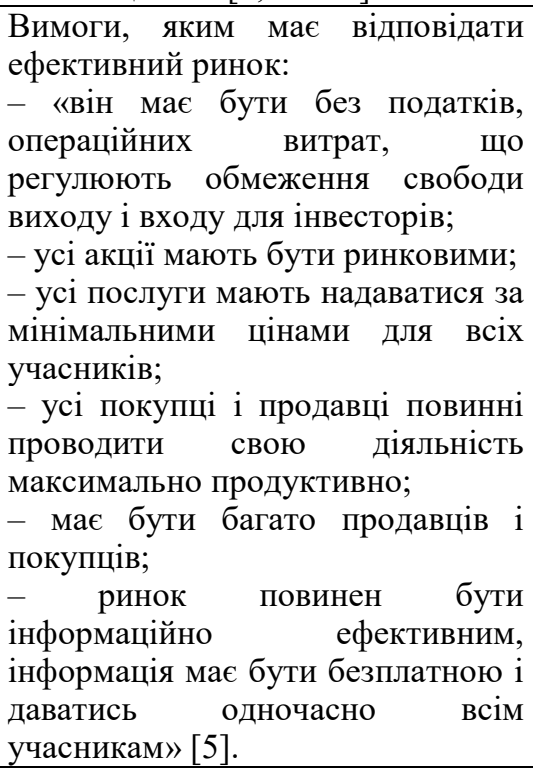 & $\begin{array}{l}\text { Eфективність розподілу - пов'язана } \\
\text { iз розподільною фунцією } \\
\text { фінансового ринку, і передбачає } \\
\text { такий розподіл фондів на біржі, щоб } \\
\text { забезпечити їх найефективніше } \\
\text { використання. } \\
\text { «цінова ефективність - означає, що } \\
\text { «у будь-який час ціни акцій повинні } \\
\text { відбивати всю інформацію про події, } \\
\text { що відбулися, а також усі події, що } \\
\text { можуть відбутися на ринку в } \\
\text { майбутньому» [5]. } \\
\text { Операційна ефективність- полягає } \\
\text { в тому, що ефективність фінансового } \\
\text { ринку обернено пропорційна } \\
\text { витратам, які інвестори несуть при } \\
\text { здійсненні транзакцій, тому щоб } \\
\text { бути ефективним, ринок має } \\
\text { забезпечувати операційні затрати за } \\
\text { найнижчими цінами. }\end{array}$ \\
\hline $\begin{array}{l}\text { Концепція } \\
\text { фінансового витрат } \\
\text { посередництва, зокрема, } \\
\text { модель акумульованого } \\
\text { капіталу } \\
\text { Р. Лукас та П. Ромер) }\end{array}$ & $\begin{array}{l}\text { Ефективність фінансового ринку } \\
\text { розглядають як величину, } \\
\text { обернену різниці відсоткових } \\
\text { ставок по кредитах і депозитах в } \\
\text { банківській системі }[6, \text { с. } 68]\end{array}$ & \\
\hline
\end{tabular}

Примітка. Складено автором за джерелами [1, 2, 4, 5, 6].

Це пояснюється тим, що кожен учасник ринку володіє певним обсягом інформації в міру своїх можливостей та компетентності. Деякі з гравців ринку володіють унікальною інформацією, проте більшості учасників ринку доводиться задовольнятися 
загальнодоступними даними. I все ж ніхто з гравців не може знати більше, ніж всі учасники ринку разом взяті. Згідно з цим підходом, розрізняють три форми ефективності фінансового ринку: слабку, середню (напівсильну) і сильну, залежно від того, що мається на увазі під всією доступною інформацією (див. табл. 1). Причиною ж неефективності ринку є інформаційна асиметрія, коли інформація доступна лише деяким, а не усім учасникам ринку. Асиметричність інформації породжує певну невизначеність на фінансовому ринку. У цьому випадку канали впливу фінансового ринку на реальний сектор економіки базуються на недостатній або неточній, часом суб'єктивній інформації про об'єкти інвестування, що стає причиною неефективних інвестицій.

В інформаційних джерелах наводяться такі основні постулати, на яких базується поняття ефективності фінансового ринку:

«1) інформація стає доступною для всіх учасників ринку одночасно, і її отримання не пов'язане 3 якими-небудь витратами;

2) відсутні трансакційні витрати, податки та інші фактори, що можуть заважати укладанню угод;

3) угоди, що здійснюються окремою фізичною чи юридичною особою, не можуть вплинути на загальний рівень цін; вигоду» [3].

4) усі суб'єкти ринку діють раціонально, намагаючись максимізувати очікувану

Проте, як показує практика, усі ці чотири умови ефективності фінансового ринку не дотримуються на жодному реальному ринку. Так, для отримання інформації витрачається час, суб'єкти ринку зазнають певних трансакційних витрат, сплачують податки. При цьому недотримується принцип одночасності отримання інформації всіма учасниками ринку. Одні з учасників ринку отримують інформацію раніше за інших. У зв'язку з невиконанням цих умов прийнято розрізняти ідеальну інформаційну та економічну ефективність фінансового ринку. На ідеально ефективному фінансовому ринку дотримуються усі вище зазначені умови ефективності ринку, і ціни відбивають усю відому інформацію. Якщо з'являється нова інформація, вона миттєво викликає зміну цін, тому отримання надприбутків $\epsilon$ щасливою випадковістю. «На економічно ефективному ринку ціни не можуть негайно реагувати на появу нової інформації, однак за умови елімінування інформаційних та трансакційних витрат надприбутки відсутні і на цьому ринку» [3].

Розвив та розширив концепцію ефективного фінансового ринку Ю. Фами інший американський економіст, Лауреат Нобелівської премії з економіки 1990 року Вільям Шарп (англ. William Forsyth Sharpe), який увів поняття «інвестиційна вартість цінного папера». Інвестиційну вартість вчений розглядає як справедливу вартість цінного папера. На думку В. Шарпа, «на ефективному ринку всі цінні папери продаються за ефективними цінами. Цінних паперів із завищеними чи заниженими цінами на такому ринку не буде, оскільки нова інформація негайно відбивається на цінах. Із цього випливає розширене визначення ефективного ринку: ринок є ефективним, якщо, використовуючи одержану інформацію, не можна отримати відмінний від нормального прибуток або надприбуток» [4, c. 109].

Альтернативною концепцією до гіпотези ефективного ринку є підхід ще одних американських вчених-економістів Т. Коупленда і Дж. Вестона. В своїй праці «Financial Theory and Corporate Policy» автори наводять вимоги, яким має відповідати ефективний ринок (див. табл. 1). Відповідно до цих вимог існують три форми ефективності ринку капіталів: «ефективність розподілу», «цінова ефективність», «операційна ефективність». Всі ці три форми ефективності ринку капіталів пов'язані між собою і передбачають наявність одна одної. 
Слід зазначити, що запропоновані американськими економістами концепції ефективності фінансового ринку, не дивлячись на їх прагматизм і значимість для економіки, стосуються переважно однієї складової фінансового ринку - ринку цінних паперів або ринку капіталів. До того ж, як показала практика, не всі висунуті умови ефективності фінансового ринку дотримуються на реальному ринку.

В наукових джерелах поширена ще одна концепція ефективності фінансового ринку, прихильники якої розглядають їі з точки зору витрат фінансового посередництва. До витрат цієї категорії можна віднести виплати комісійних винагород фінансовим інститутам за надані послуги, різні трансакційні витрати, пов'язані зі здійсненням інвестицій на ринку цінних паперів. В основу оцінки витрат фінансового посередництва покладено підхід зарубіжних вчених К. Ерроу, Р. Лукаса та П. Ромера, зокрема, модель акумульованого капіталу (так звана модель «АК»). Згідно з цим підходом, як показники ефективності можна використовувати сукупний обсяг накладних витрат комерційних банків або середнє значення трансакційних витрат на оформлення угод з купівліпродажу цінних паперів на національному біржовому ринку. Досить часто ефективність фінансового ринку розглядають як величину, обернену різниці відсоткових ставок по кредитах і депозитах в банківській системі [6, с. 68]:

$$
\emptyset=\frac{1}{\left(r_{k}-r_{d}\right)}
$$

де $\varnothing$ - ефективність фінансового ринку;

$\mathrm{r}_{\mathrm{k}}, \mathrm{r}_{\mathrm{d}}$ - відсоткові ставки по кредитах і депозитах відповідно, виражені в частках.

Це рівняння є актуальним для економік, в яких роль банківських інститутів переважає в складі фінансового посередництва на фінансовому ринку. Проте суперечність цього рівняння полягає в тому, що з одного боку створення ефективного фінансового ринку та його розвиток передбачають значних витрат на розбудову системи фінансових посередників, тому витрати фінансового посередництва будуть прямо пропорційні ефективності фінансового ринку. 3 іншого боку, - обернено пропорційні, оскільки завдання ефективного фінансового ринку - мінімізувати ці витрати для збільшення доходності фінансових операцій. Отже, чим вище значення $\emptyset$, тим вище ефективність фінансового ринку.

На нашу думку, макроекономічну ефективність фінансового ринку та її роль у забезпеченні стабільного розвитку соціально-економічних систем, в першу чергу, визначає розподільна (перерозподільна) функція фінансового ринку. Відомо, що головне завдання фінансового ринку в ринковій економіці - це передача вільних фінансових ресурсів від тих, хто має їхній надлишок, до тих суб'єктів ринку, які їх потребують для власного виробничого і позавиробничого розвитку. Тобто фінансовий ринок виконує роль фінансового посередника при трансформації заощаджень в інвестиції, головне призначення якого, - ефективне розподілення коштів між різними сферами економіки. У свою чергу, це в подальшому стимулює економічне зростання, технологічні інновації, створення «нової вартості», наповнення бюджетів різних рівнів податками, ріст зайнятості населення, тобто все те, що, само по собі, або в поєднанні з іншими факторами, на думку багатьох експертів, є показниками «суспільного добробуту».

Ефективний фінансовий ринок має бути рушійною силою, що стимулює стабільний розвиток і позитивні зрушення в економіці, забезпечуючи підприємства інвестиційно-кредитними ресурсами. Проте, не всі сегменти фінансового ринку безпосередньо приймають участь у постачанні фінансових ресурсів підприємствам реального сектора економіки. Основні канали фінансового ринку, через які здійснюється 
приплив коштів в економіку, це інструменти та суб'єкти грошово-кредитного ринку (або ринку позичкового капіталу) та фондового ринку.

3 іншого боку, фінансовий ринок - це багатогранна сфера, яка об'єднує як реальних товаровиробників, які залучають капітал для фінансування своєї виробничої діяльності та здійснення інвестицій, так і спекулянтів, або гравців ринку, які використовують різноманітні інструменти фінансового ринку, зокрема похідні фінансові інструменти, з метою отримання спекулятивного прибутку. До того ж слід відзначити зростання останнім часом частки спекулятивних операцій на сучасному фінансовому ринку. Ринок похідних фінансових інструментів не $\epsilon$ безпосереднім постачальником інвестиційних ресурсів. Проте, гравці ринку можуть здійснювати значний вплив на механізм прийняття інвестиційних рішень, які часто приймаються в умовах невизначеності на фінансовому ринку, що викликано інформаційною асиметрією. Як наслідок, існує конфлікт між інтересами спекулянтів, які прагнуть до максимізації свого прибутку, і завданнями макроекономічного розвитку країни. В умовах невеликої ресурсної бази фінансового ринку, що характерне переважно для економік країн, що розвиваються, виведення фінансових ресурсів на ринок похідних фінансових інструментів, які є більш дохідними, може призвести до скорочення можливостей нефінансових корпорацій щодо залучення капіталу.

Для аналізу ефективності фінансового ринку в розрізі основних його складових використовують фундаментальний i технічний аналіз. У фінансовій літературі, як зазначалося вище, найчастіше зустрічається методика оцінки ефективності фінансового ринку за його інформаційною функцією, в результаті якої виділяють три степені ефективності фінансового ринку: слабку, середню та сильну. Деякі науковці поділяють слабку форму ефективності ринку ще на декілька рівнів, наприклад, гіпотеза випадкового блукання RW1 та RW2. Аналіз інформаційної ефективності фондового ринку зазвичай передбачає дослідження динаміки фондових індексів. Під час аналізу ринку позичкового капіталу на інформаційну ефективність аналізують динаміку відсоткових ставок по кредитах або відношення приросту виданих кредитів до приросту відсоткових ставок [7, с. 59].

Вплив фінансового ринку на економічне зростання, суттєво варіюється залежно від рівня розвитку країни (розвинуті країни, країни, що розвиваються, бідні країни), рівня доходу на душу населення (високий рівень доходу, середній, вище чи нижче середнього рівня, низький дохід), внутрішньої та зовнішньої економічної політики, розвитку інфраструктури фінансового сектору (наявність чи відсутність тих чи інших фінансових установ) тощо. В країнах з невисоким рівнем економічного розвитку в складі фінансового сектору домінують комерційні банки, проте, як в більш розвинутих країнах активними на фінансовому ринку є національні фондові біржі.

Для порівняльного аналізу впливу стану розвитку ринку цінних паперів на економічний розвиток різних країн аналізують, зазвичай, розмір фондового ринку за інформацією про ринкову капіталізацію та ліквідність фондового ринку у відсотковому відношенні до ВВП, складеною Всесвітньою федерацією бірж. Для характеристики кредитного ринку використовують, зокрема, такі показники, що надаються Міжнародним Валютним Фондом, як частка виданих комерційними банками кредитів у відсотковому відношенні до ВВП, кількість філій комерційних банків на 100 тис. дорослого населення, розмір спреду відсоткових ставок тощо. При цьому, проведення порівняльного аналізу за різними країнами може бути обмежене концептуальними відмінностями або статистичними недоліками, такими як неточна звітність і відмінності в стандартах бухгалтерського обліку в різних країнах світу, відсутність статистичних даних тощо. 
Дослідження ключових показників стану розвитку основних сегментів фінансового ринку в країнах 3 різним рівнем доходу на душу населення, що здійснювалося за даними Групи Світового банку, показало, що національні фінансові ринки економічно розвинутих країн (з високим і вище середнього рівня доходом на душу населення) займають лідируюче положення в ключових сегментах світового фінансового ринку (табл. 2).

Таблиця 2

Ключові показники стану розвитку фінансового ринку за групами країн станом на 2019 рік $^{*}$

\begin{tabular}{|c|c|c|c|c|c|}
\hline \multirow[b]{2}{*}{ Показники } & \multicolumn{5}{|c|}{ Країни з рівнем доходу на душу населення } \\
\hline & високим & $\begin{array}{c}\text { вище } \\
\text { середнього } \\
\text { рівня }\end{array}$ & $\begin{array}{c}\text { середні } \\
\text { м }\end{array}$ & $\begin{array}{c}\text { нижче } \\
\text { середнього } \\
\text { рівня }\end{array}$ & низьким \\
\hline $\begin{array}{l}\text { Частка внутрішніх кредитів, } \\
\text { наданих приватному сектору } \\
\text { банками, у \% до ВВП }\end{array}$ & 81,5 & 120,8 & - & 44,4 & 12,9 \\
\hline $\begin{array}{l}\text { Кількість відділень комерційних } \\
\text { банків на кожні } 100000 \text { дорослого } \\
\text { населення }\end{array}$ & 19,6 & 14,4 & 11,2 & 8,9 & 3,1 \\
\hline $\begin{array}{l}\text { Спред відсоткових ставок (різниця } \\
\text { між кредитною та депозитною } \\
\text { відсотковими ставками), \% }\end{array}$ & - & 4,9 & 5,9 & 6,9 & 9,4 \\
\hline $\begin{array}{l}\text { Ринкова капіталізація лістингових } \\
\text { вітчизняних компаній, в \% до ВВП }\end{array}$ & 118,4 & 60,0 & 60,2 & 61,1 & - \\
\hline $\begin{array}{l}\text { Ліквідність фондового ринку } \\
\text { (вартість акцій, що торгуються), в } \\
\text { \% до ВВП }\end{array}$ & 91,4 & 93,9 & 81,4 & 26,9 & - \\
\hline
\end{tabular}

Примітка. Складено автором на основі даних The World Bank [8].

Як відомо, кредити є важливою ланкою передачі грошей; вони фінансують виробництво, споживання та формування капіталу, що, у свою чергу, впливає на економічну діяльність. Згідно даних табл. 2, такі ключові показники кредитного ринку як частка кредитів, виданих комерційними банками приватному сектору, у відсотках до ВВП та кількість відділень комерційних банків на 100 тис. дорослого населення, у розвинутих країнах суттєво перевищують середньосвітовий рівень чи показники країн, що розвиваються. Чим нижчий дохід населення і відповідно нижче рівень економічного розвитку країни, тим ширша величина спреду відсоткових ставок в банківській системі таких країн, тобто з більшими втратами банківська система перетворює депозити домогосподарств на кредити підприємствам. Відповідно, якщо аналізувати величину обернену цьому спреду, то ії збільшення буде асоціюватися зі збільшенням ефективності фінансового ринку, що буде характерне для високо розвинутих країн.

Як банківські системи, так і фондові ринки підсилюють економічне зростання. Для країн 3 розвинутою економікою та високими доходами на душу населення характерне високе значення відношення капіталізації фондового ринку до ВВП, порівняно 3 бідними країнами (табл. 2). Відкриті економіки 3 обгрунтованою макроекономічною політикою, хорошими правовими системами та захистом прав акціонерів залучають більший акціонерний капітал i, отже, мають більші фінансові ринки. Все це підкреслює важливість макроекономічної ролі фінансового ринку та його вплив на соціально-економічний розвиток країн.

Отже, за макроекономічною роллю в ринковій економіці, ефективність фінансового ринку нами визначається як його здатність забезпечувати ефективний перерозподіл ресурсів, спрямовуючи їх в реальний сектор економіки, що призводить до 
стабільного розвитку соціально-економічних систем. Основними суб'єктами реального сектору економіки є нефінансові корпорації, основною діяльністю яких є виробництво ринкових товарів чи надання нефінансових послуг. Отже, в даному контексті, ефективність фінансового ринку можна оцінити тим, в якій мірі він забезпечує підприємства реального сектору економіки інвестиційними та кредитними ресурсами. Інвестиційні ресурси підприємства отримують шляхом розміщення власних акцій. Кредитні ресурси підприємства залучають на умовах платності і повернення шляхом взяття банківських кредитів чи випуску власних корпоративних облігацій. Ефективність перерозподілу ресурсів можна охарактеризувати обсягом ресурсів за параметрами терміновості, платності і повернення, що відповідає потребам позичальників нефінансових корпорацій, в структурі сукупного обсягу ресурсів, мобілізованих на фінансовому ринку. Іншими словами, ефективність фінансового ринку за його розподільною функцією можна оцінити за показником співвідношення суми реально залученого капіталу нефінансовими корпораціями та сукупної ресурсної бази фінансового ринку.

Ресурси фінансового ринку визначаються його масштабами, обсягом i специфікою грошової пропозиції. Переважна частина дослідників фінансового ринку, i ми 3 ними погоджуємося, визначають сукупний масштаб фінансового ринку як суму обсягів кредитного і фондового ринків. При цьому, окремі науковці-експерти, додатково розділяють обсяг фондового ринка на два сегменти: ринок акцій і ринок облігацій. Отже, керуючись моделлю, що запропонована Д. Блюмом, К. Федермайєром, Г. Фінком та П. Хаіссом [9, с. 50], масштаб фінансового ринку кількісно можна представити сумою:

Масштаб фінансового ринку = Обсяг кредитного ринку + Обсяг фондового ринку = $=$ Внутрішній кредит + Капіталізація ринку акцій + Сума непогашених облігації в обігу.

Оскільки абсолютний розмір масштабу фінансового ринку не завжди $є$ репрезентативною величиною, прийнято визначати його відносну величину шляхом співвідношення з обсягом ВВП.

Ефективність фінансового ринку полягає не лише в перерозподілі коштів, вони повинні надаватися на умовах, що забезпечують розвиток реального сектору економіки ріст обсягів виробництва продукції, оновлення основних засобів, технологічний розвиток тощо. В іншому випадку говорити про високу ефективність та розвиток немає сенсу.

Наскільки ефективно ринок справляється зі своєю роллю багато в чому залежить також від функціонування в країні дієвої системи державного регулювання фінансового ринку. Так, в своєму дослідженні Ж.В. Гарбар, підтримуючи думку іншого вченого Н. Звягінцевої, наводить такі критерії оцінки ефективності виконання функцій державними органами регулювання фінансового ринку: «технологічні (сумарні обороти ринку, стабільність оборотів, сумарна капіталізація ринку, стабільність капіталізації, кількість ліквідних цінних паперів на ринку, ступінь демонополізації ринку тощо); соціально-економічні (питома вага доходів від цінних паперів у сукупному доході населення, ступінь рівномірності розподілу цих доходів серед населення, частка цінних паперів у заощадженнях населення, ступінь рівномірності розподілу цієї частки серед населення, питома вага власників цінних паперів серед населення тощо)» [10, с. 34].

Висновки. Отже, зважаючи на існуюче в теорії твердження, що «ефективність являє собою ступінь досягнення поставлених цілей», ефективність фінансового ринку в цілому можна оцінювати за ефективністю виконання ним покладених на нього завдань. На нашу думку, загалом робити висновок про те, наскільки фінансовий ринок $\epsilon$ ефективним в країні для всіх учасників ринку, можна за такими загальними критеріями, 
як: наявність в країні належних умов для ефективної мобілізації та розміщення на ринку вільних фінансових ресурсів; захищеність прав інвесторів та інших учасників фінансового ринку; прозорість та відкритість ринку; наявність розвиненої мережі інституційних інвесторів; розвиток добросовісної конкуренції на фінансовому ринку та ін. Все це, у свою чергу, проявлятиметься у припливі інвестицій (як зовнішніх, так і внутрішніх); високому рівні участі населення у діяльності ринку (ріст частки заощаджень населення в ресурсній базі ринку); наявності великої кількості ліквідних та інвестиційно привабливих фінансових інструментів; високій ліквідності та капіталізації ринку тощо. Результатом ефективно функціонуючого фінансового ринку має стати соціально-економічний розвиток країни та зростання добробуту населення.

\section{Список бібліографічного опису:}

1. Ніколаєва А.М. Роль ефективності фінансового ринку в управлінні економічними системами. Функціональні аспекти фінансового менеджменту як інструменту управління економічними системами : монографія / за ред. д.е.н., проф. І.М. Вахович Луцьк: Відділ іміджу та промоції Луцького НТУ, 2021. С. 95-106.

2. Fama E. F. Market efficiency, long-term returns, and behavioral finance. Journal of financial economics. 1998. T. 49. PP. 283-306.

3. Эффективность рынка (Market Efficiency) - это. URL: https://economicdefinition.com/Business/Effektivnost_rynka_Market_Efficiency_eto.html\#h3-0 (дата звернення: 10.06.2021р.).

4. Шарп У. Ф., Александер Г. Дж., Бэйли Дж. В. Инвестиции. 1997. 1028 с.

5. Суторміна В. М. Фінанси зарубіжних корпорацій: підручник. К.: КНЕУ, 2004. 566 с.

6. Столбов М. И. Финансовый рынок и экономический рост: контуры проблемы. М. : Научная книга. 2008. 201 с.

7. Иванченко И. С. Методы тестирования эффективности финансового рынка. Финансовая аналитика: проблемы и решения. 2015. №21 (255). С. 58-68.

8. World Development Indicators: Financial access, stability and efficiency. Stock markets // The World Bank. URL : http://wdi.worldbank.org/table (дата звернення: 15.06.2021 p.).

9. Blum D., Federmaier K., Fink G., Haiss P. The Financial-Real Sector Nexus: Theory and Empirical Evidence. IEF Working Paper. 2002, No. 43, P. 50.

10. Гарбар Ж.В. Вплив державних регуляторів на розвиток фінансового ринку. Агросвіт. 2014. №8. С. 30-36.

\section{References:}

1. Nikolaieva A.M. Rol efektyvnosti finansovoho rynku v upravlinni ekonomichnymy systemamy. Funktsionalni aspekty finansovoho menedzhmentu yak instrumentu upravlinnia ekonomichnymy systemamy : Monohrafiia / za red. d.e.n., prof. I.M. Vakhovych Lutsk: Viddil imidzhu ta promotsii Lutskoho NTU, 2021, pp. 95-106 [in Ukrainian].

2. Fama E. F. Market efficiency, long-term returns, and behavioral finance. Journal of financial economics. 1998. T. 49, pp. 283-306.

3. E'ffektivnost' rynka (Market Efficiency) - e'to. Available at: https://economicdefinition.com/Business/Effektivnost_rynka_Market_Efficiency_eto.html\#h3-0 (accessed 10.06.2021) [in Russsian].

4. Sharp U. F., Aleksander G. Dzh., Be'jli Dzh. V. Investicii. 1997. 1028 p. [in Russsian].

5. Sutormina V. M. Finansy zarubizhnykh korporatsii: pidruchnyk. K., KNEU, 2004. 566 p. [in Ukrainian].

6. Stolbov M. I. Finansovyj rynok i e'konomicheskij rost: kontury problemy. Moscow, Nauchnaya kniga, 2008. 201 p. [in Russsian].

7. Ivanchenko I. S. Metody testirovaniya e'ffektivnosti finansovogo rynka. Finansovaya analitika: problemy i resheniya. 2015. No21 (255), pp. 58-68. [in Russsian].

8. World Development Indicators: Financial access, stability and efficiency. Stock markets, The World Bank. Available at: http://wdi.worldbank.org/table (accessed 15.06.2021).

9. Blum D., Federmaier K., Fink G., Haiss P. The Financial-Real Sector Nexus: Theory and Empirical Evidence. IEF Working Paper. 2002, No. 43. P. 50.

10. Harbar Zh.V. Vplyv derzhavnykh rehuliatoriv na rozvytok finansovoho rynku. Ahrosvit. 2014, No 8, pp. 30-36. [in Ukrainian].

Дата подання публікації 10.08.2021p. 